\title{
ОСОБЕННОСТИ ВЗРЫВНОЙ СЕЙСМИЧНОСТИ НА ТЕРРИТОРИИ РЕСПУБЛИКИ КАРЕЛИЯ ЗА 2017-2018 ГГ.
}

\author{
И. А. Зуева \\ Институт Геологии КарНЦ РАН, г. Петрозаводск
}

Поступила в редакцию 14 декабря 2018 г.

\begin{abstract}
Аннотация: изучены особенности взрывной сейсмичности на территории Республики Карелия по сейсмическим данным за 2017-2018 г2. В регионе в настоящее время действуют около 30 карьеров. Взрывные работы проводятся в дневное время с зарядами взрывчатого вещества в диапазоне от 10-1000 тонн. Все крупные взрывы рассредоточены и проводятся с коротким замедлением. По результатам обработки сейсмических сигналов, выделены «зоны» техногенной сейсмичности. Приведены волновые формы записей. Для идентификации техногенных событий на сейсмических записях в выделенных «зонах» применялся спектральный анализ. Показань зависимость амплитуды спектров событий от расстояния до сейсмической станции и их числовые характеристики. Магнитуды сейсмических событий от взрывов изменяются в пределах $1-2,5$.
\end{abstract}

Ключевые слова: промышленные взрывы, сейсмические станции, волновые формы, спектр.

\section{PECULIARITIES OF EXPLOSIVE SEISMICITY IN THE TERRITORY OF THE REPUBLIC OF KARELIA FOR 2017-2018}

\begin{abstract}
Republic of Karelia were studied using seismic data for 2017-2018. About 30 quarries are currently operating in the region. Blasting operations are carried out in the daytime with explosive charges ranging from 10-1000 tons. All large explosions are dispersed and carried out with a short deceleration. According to the results of seismic signal processing, "zones» of technogenic seismicity are highlighted. The waveforms of the records are given. Spectral analysis was used to identify man-made events on seismic records in selected "zones". The dependence of the amplitude of the spectra of events on the distance to the seismic station and their numerical characteristics are shown. The magnitudes of seismic events from explosions vary in the range of $1-2,5$.
\end{abstract}

Keywords: industrial explosions, seismic stations, wave forms, spectrum.

\section{Введение}

Территория Республики Карелии расположена в восточной части Фенноскандинавского щита. В данном регионе четко выделяются три структурных области: центральная часть рассматриваемой территории занимает относительно устойчивый в течение всей докембрийской истории крупный участок земной коры - Карельский кратон, с северо-востока к нему примыкает линейный Беломорский складчатый пояс, а с юго-запада обширная Свекофеннская складчатая область (рис. 1) [1, 2].

Карта сейсмического районирования России ОСР97 [3] относит территорию Карелии к зонам вероятной интенсивности 5-7 баллов для периода повторяемости 5000 лет. Сейсмическая активность приурочена к палеорифту Кандалакша-Двина и ЛадожскоБотнической шовной зоне. Несмотря на относительно низкий уровень сейсмической активности, детальное изучение территории Карелии не только представляет теоретический, научный интерес, но и имеет практическое значение, заметно возросшее в связи с наличием в регионе крупных промышленных комплексов, газопроводов и гидротехнических сооружений [4].

В Карелии действует сеть сейсмических станции на базе широкополосной аппаратуры - Guralp CMG-6TD и CMG-3ESP (АЦП - GSR 24) [5]. Станции PTRZ, PITK, KOS6, PAAN установлены в специально оборудованных сейсмических павильонах на бетонные постаменты. Станция KOS6 располагается в 15 км от города Костомукша, PITK в поселке Леппясилта Питкярантского района, PTRZ в городе Петрозаводск. В 2016 г заработала станция PAAN в Лоухском районе.

По сейсмическим данным последних лет местные землетрясения были обнаружены в Лоухском районе. Причиной таких событий являются современные движения земной коры Фенноскандии, которые 
определяются тремя главными моментами: горизонтальным сжатием со стороны раздвигающегося Срединно-Атлантического рифта; вертикальным сводообразным изостатическим поднятием щита в целом; остаточным постгляциоизостатическим поднятием [4]. Промышленные взрывы являются наиболее яркими сейсмическими событиями для слабоактивной в сейсмическом отношении территории Карелии. Все крупные взрывы рассредоточены и проводятся с коротким замедлением. В условиях слабой природной сейсмичности более высокий уровень сейсмичности от взрывных работ маскирует процессы природной сейсмичности. Особенно важно уметь правильно различать на сейсмических записях местные землетрясения от техногенных взрывов. Существует множество методик распознавания местных событий [6, 7]. Цель данной работы заключалась в выделении особенностей сейсмических сигналов от взрывов, производимых на многочисленных карьерах Республики Карелии, по сейсмическим данным за 2017-2018 гг.

Результаты исследований необходимы при обработке сейсмических записей на территории Карелии, составлении каталогов сейсмичности региона.

Региональная сейсмическая сеть Карелии регулярно регистрирует очаги с магнитудой 1-2,5. Проблема разбраковки событий является чрезвычайно важной, но и очень сложной. Для интерпретации сейсмического события, прежде всего, необходимо исследовать особенности записей волновых форм. Они зависят от многих факторов, основными из которых являются: технология производства взрывов, свойства геологической среды на пути «взрывприемник» и особенности геологического строения в местах регистрации волнового поля $[5,8]$.

\section{Исходные данные}

В настоящее время в регионе действует около 30 карьеров. Взрывные работы проводятся с зарядами взрывчатого вещества (BВ) в диапазоне от 10-1000 тонн при короткозамедленном взрывании. В Костомукшском районе масса ВВ достигает от 100 до 1000 тонн, в других районах Карелии от 10 до 50 тонн. Изучались волновые формы записей взрывов на различных карьерах, на основе их анализа выделены три «зоны» техногенной сейсмичности. На (рис. 1) показано расположение сейсмических станций Карелии и эпицентров техногенных взрывов, производимых в действующих карьерах по данным за 2017 2018 гг.

\section{Анализ результатов обработки взрывов на территории Карелии}

Локация сейсмических событий проводится в программе EL_WIN, разработанной сотрудником КоФ ФИЦ ЕГС РАН В. Э. Асмингом [9]. В (табл. 1) показаны примеры основных параметров (время в очаге, координаты эпицентра, локальная магнитуда) сейсмических событий, зарегистрированных в 2017 2018 гг. Это взрывы, которые часто встречаются на

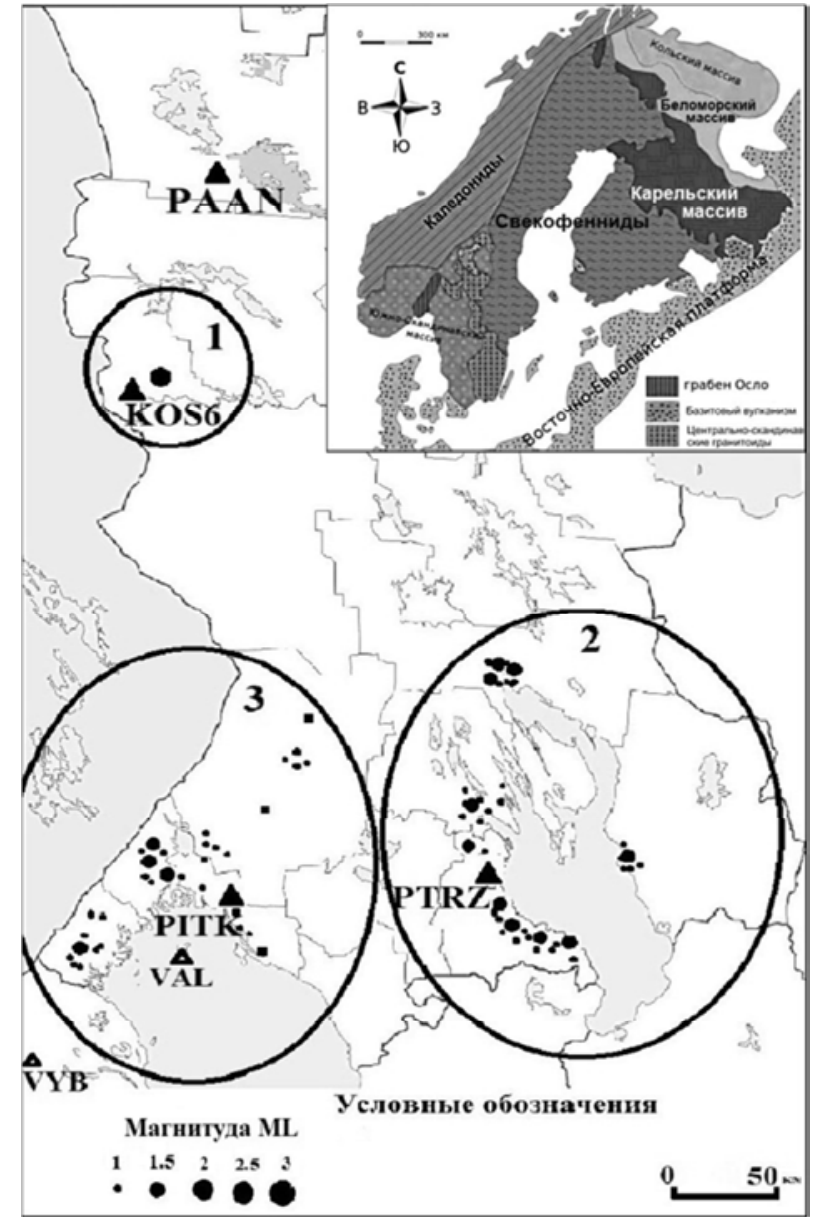

Puc. 1. Расположение эпицентров техногенных событий, сейсмических станций Карелии и «зон» техногенных событий: 1 - «Костомукшский район»; 2 - «Пудожский, Прионежский, Медвежьегорский, Кондопожский районы»; 3 - «Сортавальский, Суоярвский, Лахденпохский, Питкярантский районы».

сейсмических записях Карельской сети. Для определения координат эпицентров привлекаются записи сейсмических станций соседних регионов. Данные подтверждены сотрудниками Костомукшского горнообогатительного комбината (ГОКа) и Ростехнадзора. Выбранные события приведены в соответствии с расположением их к ближайшей сейсмической станции Карелии, а разделение на «зоны» облегчит процесс обработки.

На (рис. 2-4) представлены примеры волновых форм сейсмических событий из выделенных «зон».

Стоит отметить, что самые сильные события с магнитудой 1,5-2,5 регистрируются в Костомукшском районе. В других районах Карелии магнитуда техногенных событий изменяется в пределах 1-1,7. Слабые события сложно распознать. Такое разбиение территории на «зоны» позволит более точно идентифицировать сейсмическое событие, соотнести его к нужному району и карьеру.

Взрывы, производимые на карьерах АО «Карельский окатыш» - «зона (1)», хорошо выделяются на записях станции, установленной в Костомукшском районе (рис. 2). Эти события регистрируются всеми 
Таблица 1

Техногенные события (взрывы) на территории Карелии, зарегистрированные сейсмическими станцияи

\begin{tabular}{|c|c|c|c|c|c|c|}
\hline \multirow{2}{*}{ Дата } & \multirow{2}{*}{$\begin{array}{l}\text { Время в очаге } \\
\text { (ч:мин:сек) }\end{array}$} & \multicolumn{2}{|c|}{ Координаты эпицентра } & \multirow{2}{*}{$\begin{array}{l}\text { Магни- } \\
\text { туда }\end{array}$} & \multirow{2}{*}{$\begin{array}{c}\text { Станции, } \\
\text { записавшие событие }\end{array}$} & \multirow{2}{*}{ Карьер } \\
\hline & & Широта, ${ }^{\circ}$ & Долгота, ${ }^{\circ}$ & & & \\
\hline \multicolumn{7}{|c|}{ «Костомукшский» (1) } \\
\hline 18.01 .2018 & 09:59:53,56 & 64,709 & 30,812 & 1,8 & KOS6, PAAN, PITK & Северный \\
\hline 23.01 .2018 & $10: 00: 28,1$ & 64,785 & 30,812 & 1,9 & KOS6, PAAN, PTRZ & Западный \\
\hline 25.01 .2018 & 10:00:05,1 & 64,733 & 30,861 & 1,7 & KOS6, PAAN, PTRZ & Южный \\
\hline 30.01 .2018 & 09:59:58,71 & 64,689 & 30,666 & 2 & KOS6, PITK, PTRZ & Центральный \\
\hline \multicolumn{7}{|c|}{ «Пудожский, Прионежский, Медвежьегорский, Кондопожский» (2) } \\
\hline 09.10 .2017 & $13: 25: 20,57$ & 61,855 & 35,87185 & 1,3 & PTRZ, PITK, VAL & Большой массив \\
\hline 12.12 .2017 & $09: 20: 43,3$ & 61,296 & 35,477 & 1 & PTRZ, PITK & Рыборецкий \\
\hline 18.12 .2017 & $11: 49: 43,29$ & 62,974 & 34,325 & 1,4 & PTRZ, PITK, KOS6 & Серый \\
\hline 16.01 .2018 & $09: 32: 27$ & 62,188 & 34,258 & 1 & PTRZ, PITK & Сунский \\
\hline \multicolumn{7}{|c|}{ «Сортавальский, Суоярвский, Лахденпохский, Питкярантский» (3) } \\
\hline 10.01 .2018 & $14: 20: 52,2$ & 61,821 & 30,735 & 1,5 & PITK, VAL, VYB & Кирьявалахти \\
\hline 12.01 .2018 & 09:59:01,19 & 61,886 & 31,419 & 1,5 & PITK, VAL, VYB & Леппясюрья \\
\hline 15.01 .2018 & 11:06:09,42 & 61,556 & 30,062 & 1,5 & PITK, VAL, VYB & Яккима-2 \\
\hline 20.02 .2018 & $13: 55: 45,8$ & 61,808 & 31,218 & 1,2 & PITK, VAL, VYB & Олимп \\
\hline
\end{tabular}

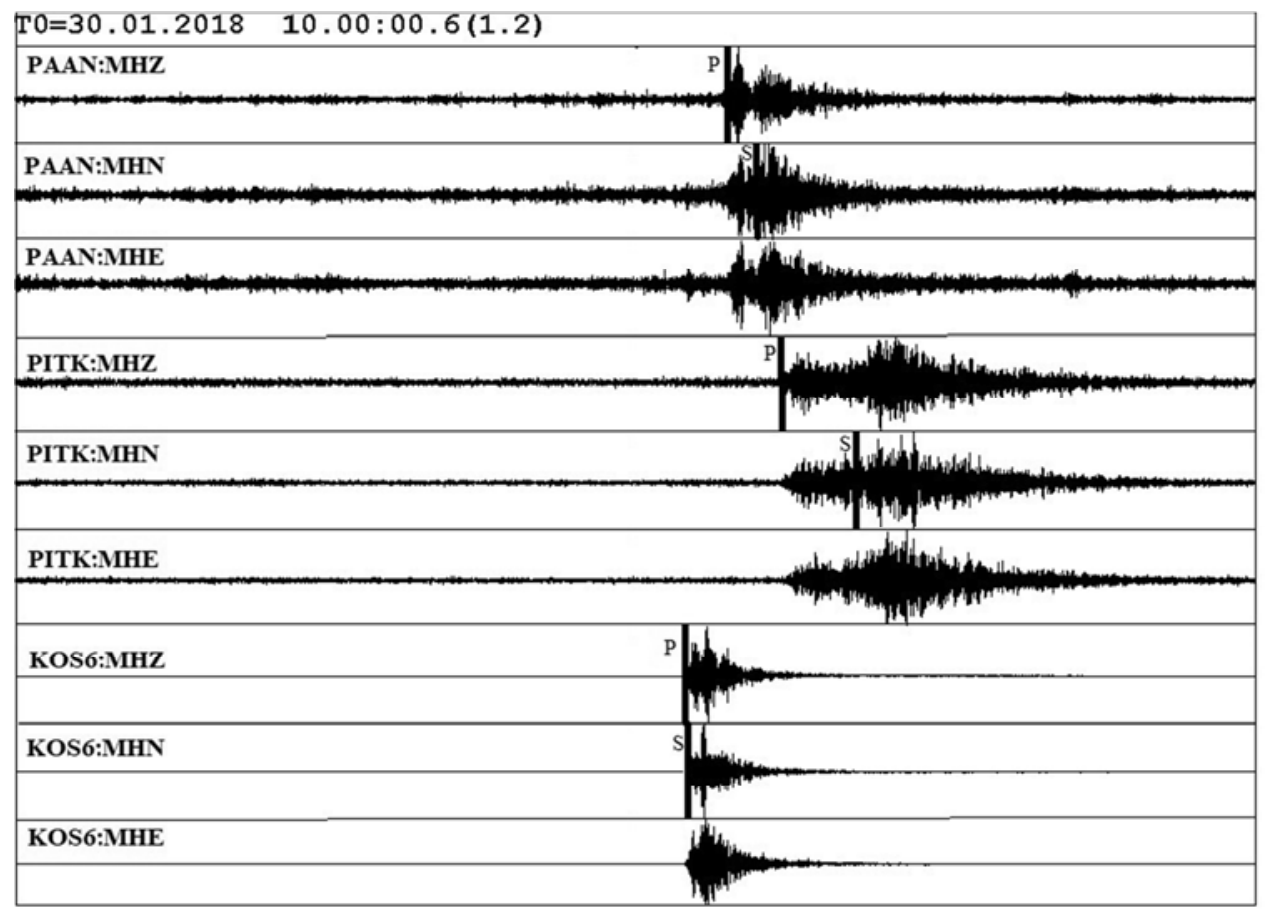

Рис. 2. Волновые формы, «зона (1)». Взрыв в Костомукшском районе на карьере «Центральный» 30.01.2018. Станции, записавшие событие: KOS6, PAAN, PITK. сейсмическими станциями Карельской сети и других регионов, если магнитуда события более $1,7$.

Частыми техногенными событиями на записях станции PTRZ являются взрывы на карьерах Прионежского, Пудожского, Медвежьегорского, Кондопожского районов - «зона (2)» (рис. 3). В обработке привлекаются данные станций PITK, VAL. Стоит отметить, что карьерные взрывы Медвежьегорского района видны на записях станции KOS6.

Взрывы в Сортавальском, Суоярвском, Лахден похском, Питкярантском районах - «зона (3)» отчетливо видны на записях станции PITK (рис. 4). В обработке событий привлекаются данные станций Ленинградской области VAL, VYB (рис. 1). Взрывы в таких районах, если магнитуда близка к значению 1,5, видны и на записях станции PTRZ. 


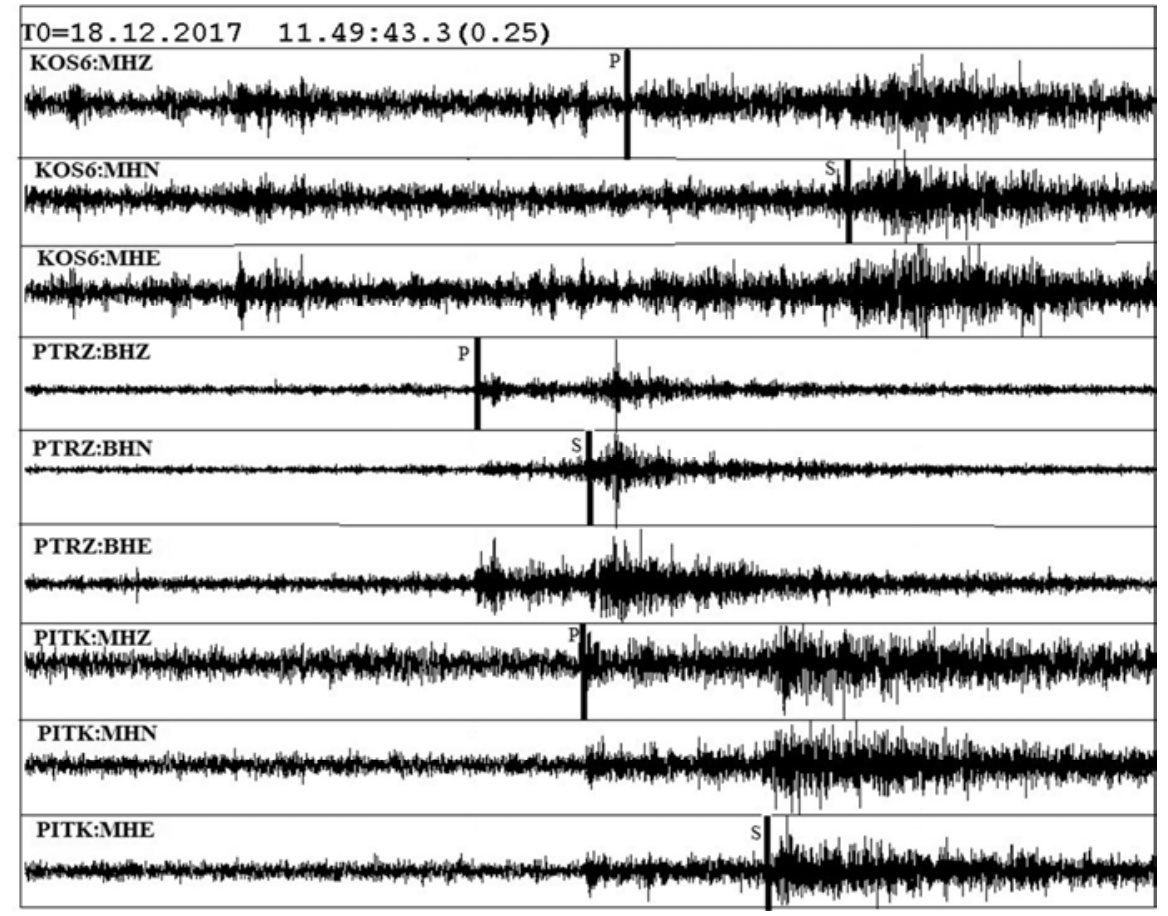

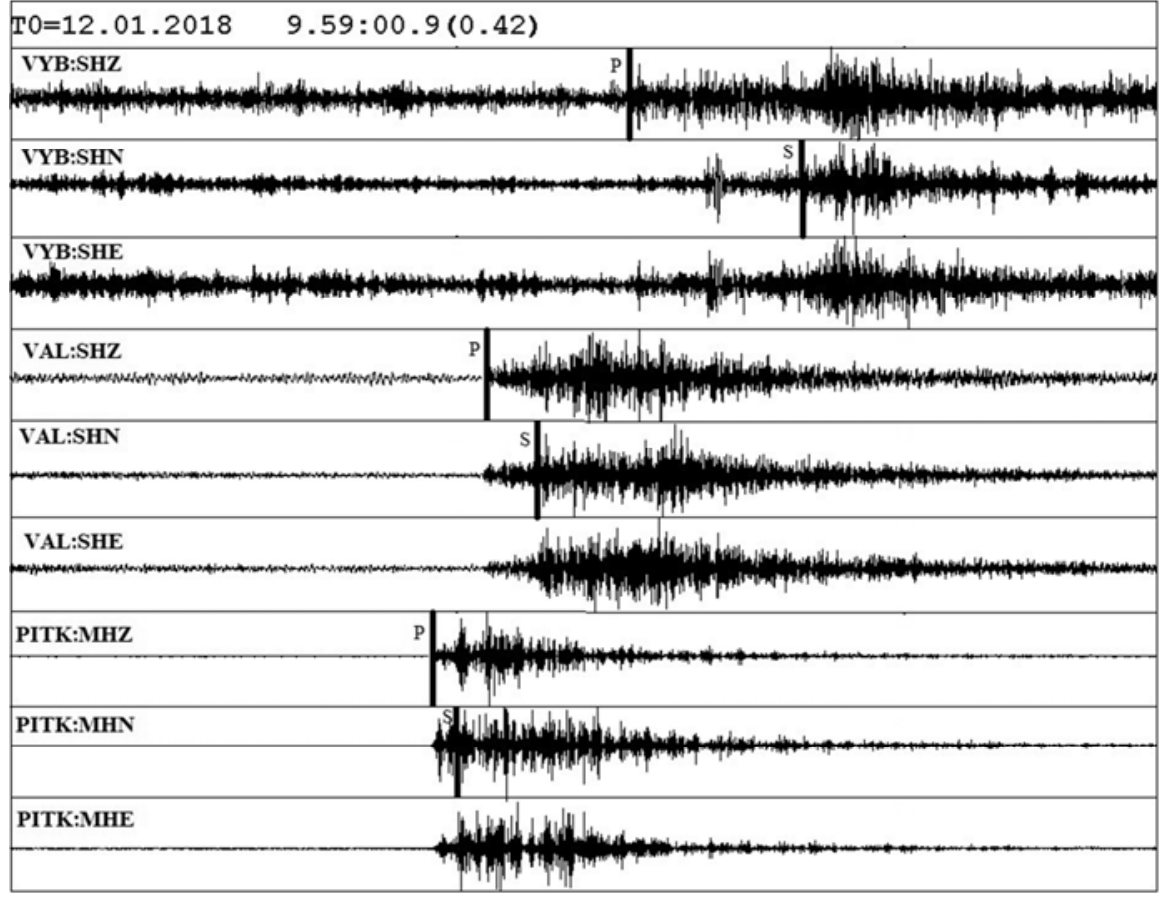

Рис. 3. Волновые формы, «зона (2)». Взрыв в Медвежьегорском районе на карьере «Серый» 18.12.2018. Станции, записавшие событие: PTRZ, PITK, KOS6.
Рис. 4. Волновые формы, «зона (3)». Взрыв в Суоярвском районе на карьере «Леппясюрья» 12.01.2018. Станции, записавшие событие: PITK, VYB, VAL.
Спектральный анализ записей. Для идентификации техногенных событий на сейсмических записях в выделенных «зонах» применялся спектральный анализ. Для построения амплитудных спектров использовалась программа WSG, разработанная сотрудниками Единой Геофизической службы Российской Академии наук (ЕГС РАН) [10].

Зачастую определить по сейсмической записи или по результатам обработки, на каком карьере произошел взрыв, затруднительно. Рассмотрим техногенные события, которые регистрируются на территории Костомукшского ГОКа (рис. 5). Взрывные работы производятся в этом районе в шести карьерах. Если сравнивать амплитуды спектров взрывов с разных карьеров, то можно оценить их удаленность до ближайшей сейсмической станции. Вследствие затухания от удаленных точек волны приходят с небольшим разбросом амплитуд [11]. Такая особенность наблюдается при сравнении амплитуд спектров взрывов, производимых на разных карьерах (рис. 6).

Для техногенных событий характерен высокочастотный спектр. Взрывы проводились с использованием короткозамедленных систем взрывания. На двух рисунках сравниваются амплитудные спектры собы- 


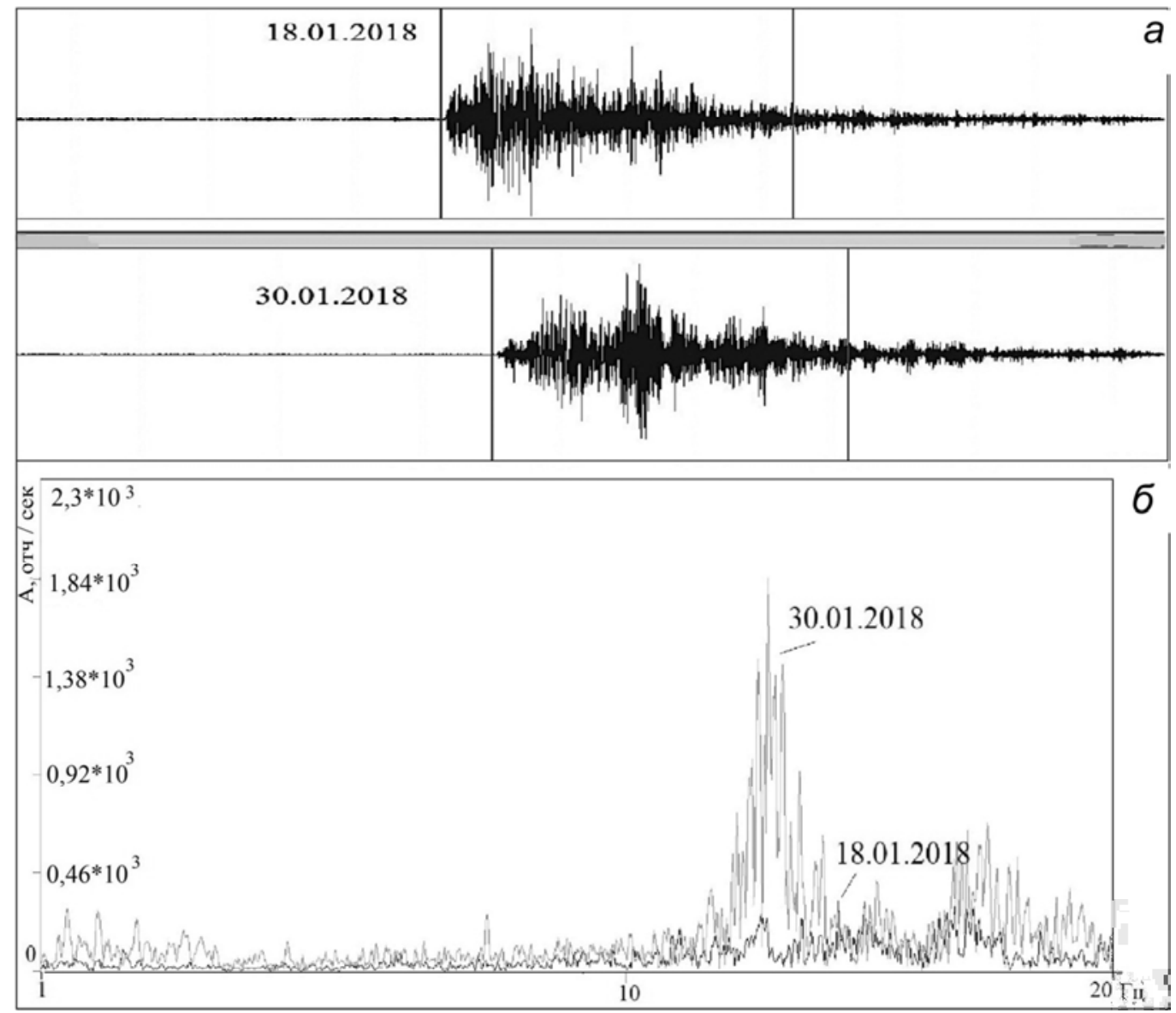

Puc. 5. Волновые формы вертикальной компоненты, полосовой фильтр 1-20 Гц (a) и амплитудные спектры сейсмической записи взрывов на карьерах «Северный» 18.01.2018, «Центральный» 30.01.2018 (данные станции КOS6) (б).

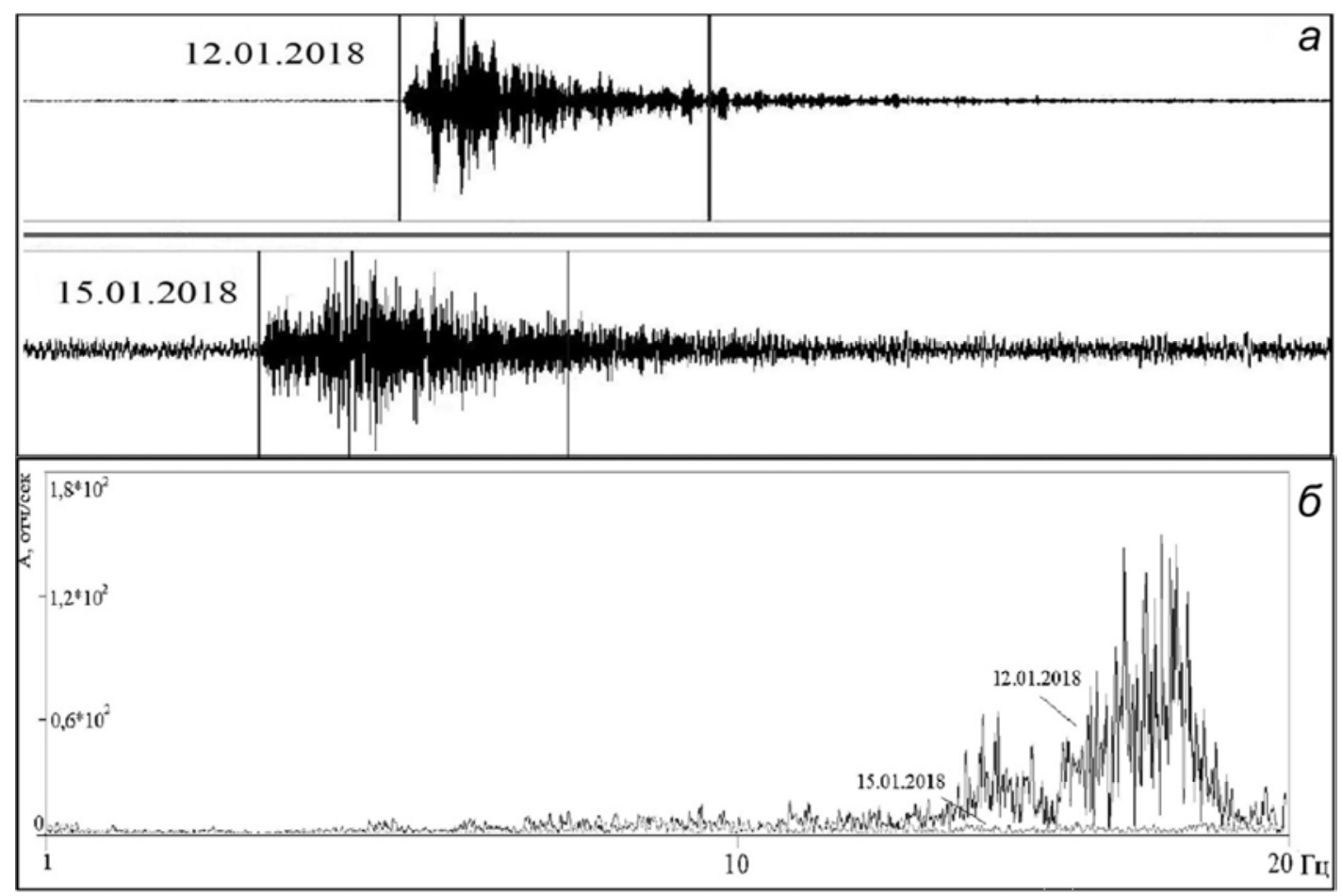

Puc. 6. Волновые формы вертикальной компоненты, полосовой фильтр 1-20 Гц (а) и амплитудные спектры сейсмической записи взрывов на карьерах «Леппясюрья» 12.01.2018, «Яккима-2» 15.01.2018 (данные станции РІTК) (б). 
тий со схожими магнитудами (табл. 1).

Карьер «Центральный» находится в 15 км от станции KOS6, «Северный» в 20 км, поэтому спектр взрыва события 18.01.2018, более сглаженный, чем события 30.01.2018. Амплитуды спектров событий на частотах от $1-10$ Гц отличаются незначительно, после 10 Гц наблюдаются всплески амплитуды на записи взрыва 30.01.2018. Максимальное значение амплитуды взрыва 30.01.2018 превосходит максимум амплитуды взрыва 18.01.2018 в 8 раз (рис. 5).

Карьер «Леппясюрья» расположен в 24 км, а карьер «Яккима 2» в 62 км от станции PITK. Амплитудный спектр записи события 15.01.2018 сглажен. На спектре взрыва 12.01.2018, который производился на карьере «Леппясюрья» наблюдаются скачки амплитуды, которые соответствуют частотам 3 и более Гц, а на высоких частотах более 10 Гц амплитудные максимумы. Максимум амплитуды взрыва 12.01.2018 превосходит максимальное значение амплитуды взрыва 15.01.2018 в 15 раз (рис. 6).

\section{Заключение}

В работе дан анализ результатов обработки местных событий и выделены особенности взрывной сейсмичности на территории Республики Карелии по сейсмическим данным за 2017-2018 гг. Все крупные взрывы рассредоточены и проводятся с коротким замедлением. Отмечены часто встречаемые события и районы с высокой сейсмической активностью. Взрывы были распределены на три «зоны» техногенной сейсмичности в соответствии с расположением до ближайшей сейсмической станции Карелии. На записях станции KOS6 регулярно до 7-9 событий в месяц регистрируются взрывы, производимые Костомукшским ГОКом. Это самые сильные техногенные события на территории Карелии, их магнитуда составляет 1,5-2,5. Станция PITK в основном записывает сейсмические события в Питкярантском, Суоярвском, Сортавальском и Лахденпохском районах. На записях станции PTRZ хорошо видны взрывы, производимые на карьерах Прионежского, Кондопожского, Медвежьегорского и Пудожского районов. Магнитуда таких событий изменяется от $1-1,7$.

По волновым формам и амплитудным спектрам сейсмических сигналов был проведен сравнительный анализ, выделены «зоны» техногенной сейсмичности. Магнитуды сейсмических событий в выде- ленных зонах отличаются незначительно. Амплитуды спектров сейсмических событий с увеличением расстояния до сейсмической станции уменьшаются.

Исследование выполнено при финансовой поддержке РФФИ в рамках научного проекта № 18-3500003.

\section{ЛИТЕРАТУРА}

1. Слабунов, А. И. Геология и геодинамика архейских подвижных поясов (на примере Беломорской провинции Фенноскандинавского щита) / А. И. Слабунов.- Петрозаводск: Карельский научный центр РАН, 2008.- 296 с.

2. Шаров, Н. В. Глубинное строение и сейсмичность Карельского региона и его обрамления / Н. В. Шаров.Петрозаводск: Карельский научный центр РАН, 2004. -353 с.

3. Уломов, В. И. Комплект карт общего сейсмического районирования территории Российской Федерации. ОСР-97. Масштаб 1:8 000 000. Объяснительная записка / В. И. Уломов, Л. С.Шумилина. - М.: ИФЗ РАН, 1999. -57 с.

4. Шаров, Н. В. Землетрясения и микросейсмичность в задачах современной геодинамики Восточно-Европейской платформы / Н. В. Шаров, А. А. Маловичко, Ю. К. Щукин. - Петрозаводск: Карельский научный центр РАН, 2007. Кн. 1: Землетрясения. $-381 \mathrm{c}$.

5. Зуева, И. А. Характерные черты сейсмических записей промышленных взрывов на Костомукшском железорудном месторождении по данным станций Карельской сети / И. А. Зуева, А. А. Лебедев // Вестник Воронежского государственного университета. Сер.: Геология. - 2017. № 2. - С. $133-141$.

6. Годзиковская, А. А. Местные взрывы и землетрясения / А. А. Годзиковская. -М.: Наука, 2000. -108 с.

7. Морозов, А. Н. Метод идентификации взрывной сейсмичности на территории Архангельской области / А. Н. Морозов // Вестник КРАУНЦ. Науки о Земле.- № 1. - Вып. 11. - 2008. - C. 177-184.

8. Глазнев, В. Н. Стохастическая модель короткозамедленного карьерного взрыва/ В. Н. Глазнев, Д. О. Плаксин, Е. Ю. Дручек // Вестник Воронежского государственного университета. Сер.: Геология. - № 2. - 2009. - С. 140-149.

9. Асминг, В. Э. Программный комплекс для автоматизированной обработки сейсмических записей «EL» / В. Э. Асминг // Приборы и методика геофизического эксперимента. Мурманск: Изд-во ООО «МИП-999». -1997.- С. 125-132.

10. Служба Срочных Донесений. - Режим доступа: http://www.ceme.gsras.ru/new/soft.htm (дата обращения 15.10.2018).

11. Шаров, H. B. Литосфера Балтийского щита по сейсмическим данным / Н. В. Шаров - Апатиты: КНЦ РАН, 1993. $-145 \mathrm{c}$.

Institute of Geology of the Karelian Research Centre of the Russian Academy of Sciences, Petrozavodsk

Zueva I. A., junior researcher

E-mail:ek92wa@mail.ru

Tel.: +7 (8142) 783471 